\title{
Prostatic Urethra Cancer pTis TNM
}

\section{Finding v8}

National Cancer Institute

\section{Source}

National Cancer Institute. Prostatic Urethra Cancer pT is TNM Finding v8. NCI Thesaurus.

Code C140447.

Urethral cancer with a finding of carcinoma in situ involving the prostatic urethra or periurethral or prostatic ducts without stromal invasion. (from AJCC 8th Ed.) 